\title{
The effects of robot-assisted movement training on daily life activities and hopelessness levels in neurorehabilitation patients
}

\author{
Filiz Ozdemir, ${ }^{1}$ Fatma Oksuz, ${ }^{2}$ Tuba Tulay Koca $^{3}$
}

${ }^{1}$ Inonu University Faculty of Health Sciences, Malatya, Turkey

${ }^{2}$ Ozgür Yasam Physical Therapy and Rehabilitation Center, Mersin, Turkey

${ }^{3}$ Sutcu ImamUniversity Faculty of Medicine, Kahramanmaras, Turkey

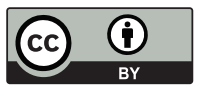

This work is licensed under a Creative Commons Attribution 4.0 International License

Received: 2019-02-24

Accepted: 2019-03-14

UDC: 616.1

J Clin Med Kaz 2019;1(51):56-60

Corresponding Author: Filiz Ozdemir, Inonu University Faculty of Health Sciences, Malatya, Turkey Tel.: +90-422-3410219-1132, +90-05321302824

Email: fciledag@gmail.com
Abstract

Objective: To determine the effects of robot-assisted movement training on daily life activities and hopelessness levels in neurorehabilitation patients.

Material and methods: The study is a randomized controlled trial. The study was conducted on 48 patients. Of these 48 patients, 8 were excluded because they did not meet the inclusion criteria. Patients who had acute internal diseases, had received botulinum toxin within 6 months before the treatment, or were unable to cooperate enough to participate in the assessments were excluded. The patients were randomly assigned to two groups: Group I consisted of 21 patients who applied gait training with a robotic device in addition to the routine neurorehabilitation programme; Group II included 19 patients in the routine neurorehabilitation programme. Hopelessness levels and daily living activities were assesed before and after treatment .Assessments were made by Beck Hopelessness Scale (BHS), and Barthel Index before and after the treatment. The IBM SPSS Statistics for Windows version 22.0 (IBM, Armonk, NY, USA) was used in the analysis of the data, and $p<0.05$ was considered to be significant.

Results: There was a statistically significant difference between the pre-treatment and post-treatment hopelessness levels of the patients included in robotic rehabilitation program $\quad(p=0.001)$, while no significant difference was found between the hopelessness levels of the cases included in routine neurorehabilitation program $(p=0.07)$. No statistical difference was found within and between the groups in terms of both pre- and post-treatment Barthel Index scores. An increase was found in the Barthel Index scores when compared with pre-treatment, although the increase was not found to be significant.

Conclusion: Robotic rehabilitation plays an active role in providing help to therapist, fulfilling motor learning principles and conducting high intensity and long-term movements. Robotic systems also have a positive effect on patients' mood and coping strategies. According to the results of our study, robotic rehabilitation in neurorehabilitation patients will provide additional advantages.

Keywords: hopelessness, daily life activities, robotic rehabilitation, neurorehabilitation patients

ЖУЙКЕ ОНАЛУТЫНДАҒЫ ПАЦИЕНТТЕРДІ КУНДЕЛІКТІ ӨМІРДЕ ЖУРУГЕ РОБОТТАЛҒАН ОҚЫТУДЫҢ ТИІМДІЛІГІ ЖӘНЕ ҮМІТСІЗДІК ДЕНГЕЙІ

Филиз Өздемір, ${ }^{1}$ Фатма Оксуз, ${ }^{2}$ Туба Тюлай Коджа ${ }^{3}$

'Физиотерапия және оңалту кафедрасы, Медицина ғылымдары факультеті, Инёню атындағы университет, Малатья, Турция

${ }^{2}$ Физиотерапия және оңалту кафедрасы, Озгюр Ясам атындағы Физиотерапия және оңалту орталығы, Мерсин, Түркия

${ }^{3}$ Физиотерапия және оңалту кафедрасы, Медицина факультеті, Сутчу Имам университеті, Кахраманмараш, Түркия

\section{ТҰЖЫРЫМДАМА} айқындау

Мақсаты: Жүйке оңалутындағы пациенттерді күнделікті өмірде жүруге роботталған оқытудың тиімділігі және үмітсіздік деңгейін

Материал мен әдістері: Зерттеу рандомизацияланған бақыланатын сынақ болып табылады. Зерттеу 48 пациенттерге жасалды, олардың 8-і өлшемдерге сәйкес келмегендіктен, алып тасталды. Жіті ішкі ауруларға шалдыққан науқастар, емдеудің алдында 6 ай бойы 
ботулотоксин қабылдағандар немесе бақылауға қатысу үшін ынтымақтаса алмайтындар да алып тасталды. Пациенттер рандомизациялы түрде екі топқа бөлінді: І-топқа жүйке оңалтуының қарапайым бағдарламасына қосымша жүруге роботталған оқытудан өткен 21 пациентер кірді; II-топқа жүйке оңалтуының қарапайым бағдарламасынан өткен 19 пациент кірді. Үмітсіздік деңгейі мен күнделікті тіршілік әрекеті емдеуге дейін және кейін бағаланып отырды. Бағалау Бектің үмітсіздік шкаласына және Бартель индексіне сәйкес емдеуге дейін және кейін жүргізілді. Ақпаратты талдау үшін IBM SPSS Statistics бағдарламасы қолданылды Windows 22.0 (IBM, Армонк, Нью-Йорк, АҚШ) нұсқасы үшін, $\mathrm{p}<0.05$ мағынасы маңызды деп есептеледі.

Нәтижелері: Оңалтудың роботталған бағдарламасына қамтылған пациенттерде емдеуге дейін және кейін үмітсіздік деңгейлері арасында статистикалық маңызды айырмашылық (p=0.001) байқалды, ал жүйке оңалтуының қарапайым бағдарламасынан өткен пациенттер арасында үмітсіздік деңгейлері арасында маңызды айырмашылық байқалмады (р=0.07). Емдеуге дейін және кейін Бартель индексінің көрсеткіштеріне қатысты топтарда және олардың арасында статистикалық айырмашылық байқалмады. Бартель индексінің көрсеткіштерінде емдеуге дейінгі көрсеткіштермен салыстырғанда ұлғаю байқалған, алайда ұлғаю айтарлықсыз болып шықты.

Қорытынды: Роботталған оңалту қозғаушы дағдыларды оқыту негізін жүзеге асыратын және жоғары қарқынды және ұзақ қозғалыстар жүргізетін терапевтерге көмектесе отырып, белсенді қатысады. Роботталған жүйелер сондай-ақ пациенттердің көңіл-күйі мен копинг-стратегияларына да жағымды әсер етеді. Біздің зерттеулердің нәтижелеріне сәйкес, жүйке оңалтуындағы пациенттер үшін роботталған оңалту қосымша артықшылықтар береді.

Негізгі сөздер: үмітсіздік, күнделікті тіршілік әрекеті, роботталған оңалту, пациенттерді жүйке оңалтуынан өткізу

\section{ЭФФЕКТЫ РОБОТИЗИРОВАННОГО ОБУЧЕНИЯ ХОДЬБЕ НА ПОВСЕДНЕВНУЮ ЖИЗНЬ И УРОВЕНЬ БЕЗНАДЕЖНОСТИ У ПАЦИЕНТОВ НА НЕЙРОРЕАБИЛИТАЦИИ}

\section{Филиз Оздемир, ${ }^{1}$ Фатма Оксуз, ${ }^{2}$ Туба Тюлай Коджа ${ }^{3}$}

${ }^{1}$ Кафедра физиотерапии и реабилитации, Факультет медицинских наук, Университет имени Инёню, Малатья, Турция

${ }^{2}$ Кафедра физиотерапии и реабилитации, Центр физиотерапии и реабилитации имени Озгюр Ясам, Мерсин, Турция

${ }^{3}$ Кафедра физиотерапии и реабилитации, Факультет медицины, Университет Сутчу Имам, Кахраманмараш, Турция

\section{PEЗЮME}

Цель: Определить эффекты роботизированного обучения ходьбе на повседневную жизнь и уровень безнадежности у пациентов на нейрореабилитации.

Материал и методы: Исследование является рандомизированным контролируемым испытанием. Исследование проведено на 48 пациентах, 8 из которых были исключены потому, что они не соответствовали критериям включения. Пациенты с острыми внутренними болезнями, те, кто получал ботулотоксин в течение 6 месяцев перед лечением или неспособные сотрудничать для участия в наблюдениях также были исключены. Пациенты рандомизированно разделены на две группы: в группу I вошел 21 пациент, которые проходили роботизированное обучение ходьбе в дополнение к обычной программе нейрореабилитации; в группу II вошли 19 пациентов, которые проходили обычную программу нейрореабилитации. Уровни безнадежности и повседневная жизнедеятельность оценивались до и после лечения. Оценка проведена согласно шкале безнадежности Бека и Индексу Бартеля до и после лечения. Для анализа информации использовалась программа IBM SPSS Statistics для версии Windows 22.0 (IBM, Армонк, Нью-Йорк, США), значение р < 0.05 считается значимым.

Результаты: Наблюдалась статистически значимая разница между уровнями безнадежности до и после лечения у пациентов, включенных в роботизированную программу реабилитации ( абилитации, не наблюдалось значительной разницы между уровнями безнадежности ( но в группах и между ними в отношении показателей Индекса Бартеля до и после лечения. Увеличение наблюдалось в показателях Индекса Бартеля при сравнении с показателями до лечения, хотя увеличение оказалось незначительным.

Заключение: Роботизированнная реабилитация принимает активное участие, помогая терапевтам, осуществляющим основы обучения моторным навыкам и проводящим высокоинтенсивные и длительные движения. Роботизированные системы также имеют положительное воздействие на настроение и копинг-стратегии пациентов. Согласно результатам нашего исследования, роботизированная реабилитация для пациентов, находящихся на нейрореабилитации, предоставит дополнительные преимущества.

Ключевые слова: безнадежность, повседневная жизнедеятельность, роботизированная реабилитация, нейрореабилитация пациентов

\section{Introduction}

Deficits that occur as a result of neurological diseases cause a direct traumatic effect on an individual's physical integrity, life cycle, and quality of life. When an individual is faced with such a diagnosis, he or she will have serious concerns about the accuracy of the diagnosis, the future of the disease, and treatment options [1].

Whether simple or life-threatening, a neurological disease can cause different responses in an individual, such as the fear of being dependent on others or losing independence completely, concerns about separation or the future, fear of death, remorse, and feelings of guilt. Although they may differ depending on the disease and the patient, these responses can cause hopelessness [2].

Hopelessness, which results from the difficulties of dealing with the disease, long-term treatment, and problems can threaten the patient's quality of life and negatively influence the patient's general perception of his or her health. Hopelessness influences patients' compliance with treatment, their efforts, motivation, and ability to cope, as well as their ability to achieve successful results from neurorehabilitation $[3,4]$.

Adapting to new technologies is one of the indispensable factors of development in modern societies. Developments in technology and robotic systems that have emerged in parallel with these developments have brought diversity to neurorehabilitation practices [5]. While robotic systems have a significant and active role in daily life activities (DLAs) and especially the mobilization of people with disabilities, they also enable repetitive and high intensity rehabilitation programmes, which are a necessity of motor learning [6,7].

In rehabilitation sessions that use robotic gait devices, the two lower extremities are moved in the correct pattern and the patient's sensorimotor learning is supported. Intense and repetitive simulation of all the phases of gait and sensory input consisting of proprioceptive feedback increases reorganization in the cortex and subcortex regions.

Continuous facilitation of the gait cycle provides regeneration of neural transmission between motor areas and sensory pathways in the brain or enables the existing transmission to become stronger [8].

It has been reported in a great number of studies that robotbased treatments increase patients' quality of life, happiness, motivation, hope and self-confidence and decrease stress and pain $[9,10]$.

The current study investigated the effects of robot-assisted movement training on daily life activities and hopelessness levels in neurorehabilitation patients. The results of the study will contribute to the assessment of changes in individuals' quality of life. 


\section{Material and methods}

This study is a randomized controlled trial. The study was conducted in a private physical therapy and rehabilitation clinic that included robotic rehabilitation practices in addition to routine neurorehabilitation programmes for neurorehabilitation patients. Patients who were diagnosed by a specialist physician between December 2017 and May 2018, had enrolled in the neurorehabilitation programme, and who agreed to participate in the study were assessed for inclusion. Inclusion criteria; being diagnosed by a specialist, being older than 18 years, being able to walk independently before the disease, and agree to participate in the study. Of these 48 patients, 8 patients who had acute internal diseases, had received botulinum toxin within 6 months before the treatment, or were unable to cooperate enough to participate in the assessments were excluded because they did not meet the inclusion criteria. The patients who were included in the study had the following conditions: hemiplegia (16), paraplegia (8), multiple sclerosis (7), ataxia (5), Parkinson's (2), transverse myelitis (1), and myopathy (1). Each patient was informed of the study's purpose and risks and signed an informed consent form. The patients were put into two groups: patients who received gait training with a robotic device in addition to the routine neurorehabilitation programme (Group 1, experiment group, $\mathrm{n}$ $=21$ ) and patients in the routine neurorehabilitation programme only (Group 2, control group, $\mathrm{n}=19$ ). A flow chart of the study is provided in Figure 1.

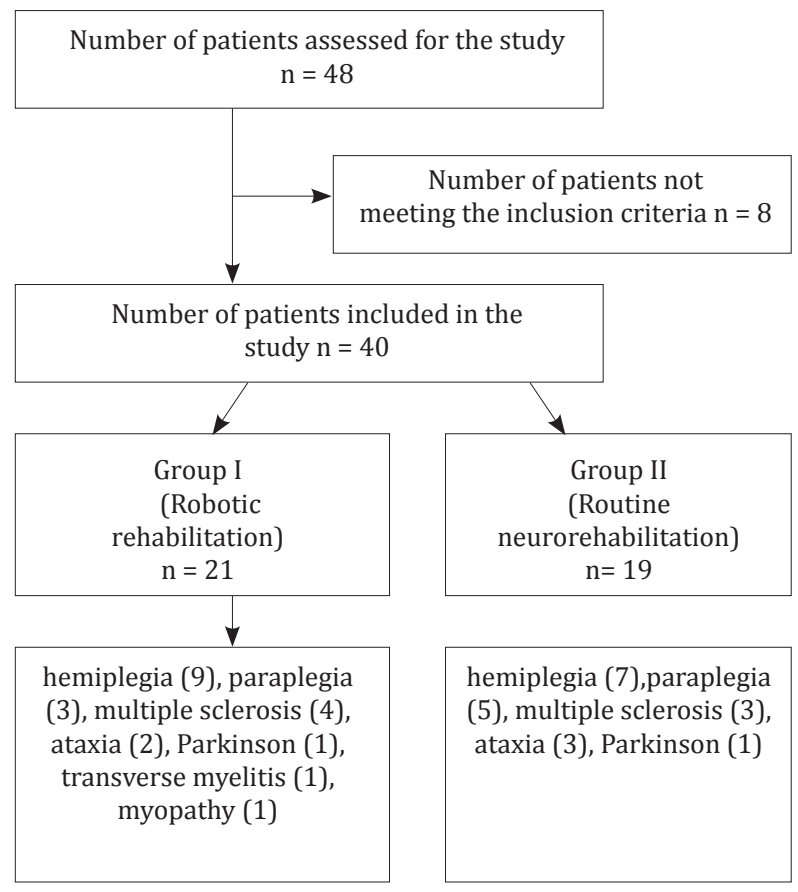

Figure 1 - Flow chart of the study

\section{Robot-Assisted Movement Training}

The patients in Group 1 who received gait training with the robotic device were included in the neurorehabilitation programme for a total of 30 sessions, 3 sessions a week for 10 weeks. Each Group 1 patient received 30 sessions of gait training with the robotic device. They had a physical therapy specialist with them in each session.

The robotic device used was a Lokomat, which is an exoskeleton-type robotic device combined with a treadmill. A Lokomat is controlled bilaterally and supports the body weight. The use of lokomat in rehabilitation is advantageous with the ability to reduce the burden of the physiotherapist and to receive feedback at the same time.

\section{Routine neurorehabilitation programme}

Each patient in Group 2 was included in the routine rehabilitation programme for a total of 30 sessions, 6 sessions a week for 5 weeks. The patients' neurorehabilitation was performed by physical therapists who were experienced in their fields. Before the treatment, each patient's functional condition was assessed by specialist physicians and physical therapists and long- and short-term goals were determined. Rehabilitation programmes were planned in parallel with these goals, which were assessed separately for each patient. The patients had 30-45 minutes of treatment in each session. For continuity, the patients worked with the same physical therapists in each session.

\section{Measurements}

\section{Personal Information Form}

The questionnaire that was used to collect data included sociodemographic variables (age, gender, marital status, level of education, working status, health insurance, economic status, and number of children) and diagnostic information (diagnosis, period of diagnosis, and previous treatments).

\section{Assessment of Daily Life Activities}

Assessments were made by a specialist physiotherapist. The Barthel Index of Daily Life Activities (DLAs) was used for the assessment of each patient's functional status. Ten primary DLAs (feeding, bathing, grooming, dressing, bowels, bladder, toilet use, transfers, mobility, and stairs) were scored, each with two to four response categories. The number of points is based on the amount of help a patient needs. The highest score means that this activity can be performed independently. The minimum total score is 0 (completely dependent); the maximum total score is 100 (completely independent). The number 60 was used as a threshold; numbers over 60 indicate independent functioning $[11,12]$

\section{Assessment of Hopelessness Levels}

Beck Hopelessness Scale is an easy and feasible. Patients were evaluated by specialist. The Hopelessness Scale developed by Beck et al. was used to determine hopelessness levels [13]. The scale is used to find out individuals' negative expectations about the future [14]. Durak conducted studies on the scale and detailed information was obtained for the validity, reliability, and factor structure of the scale. In Turkey, the scale's validity and reliability study was conducted by Seber et al. The Beck Hopelessness Scale (BHS) consists of 20 items scored between 0 and 1 [15]. A total BHS of 0-3 was assessed as a minimal level of hopelessness, while 4-8 was assessed as mild, 9-14 was assessed as moderate, and a total score of higher than 15 was assessed as severe.

\section{Data Analysis}

The study's data were uploaded to a computing environment and evaluated using the Statistical Package for the Social Sciences (SPSS) for Windows, version 22.0 (SPSS Inc., Chicago, IL). The suitability of each variable was assessed for normal distribution using the Shapiro-Wilk test. Arithmetic averages were expressed with standard errors. For the variables that were not normally distributed, the Mann-Whitney U test was used for significance between the two independent groups, while the Wilcoxon signed-rank test was used for the two dependent groups. Statistical significance was determined using a total Type I error level of 5\%.

\section{Results}

The average age of the 40 participants was $54.57 \pm 17.96$ (min: 20, max: 78); 41.4\% were male, while 58.5\% were female. The average body mass index (BMI) of the patients was $28.54 \pm$ 4.98 (min: 19.12, max: 35.86) kg/m2. 
Table 1

Distribution of demographic and clinical features between groups

\begin{tabular}{|c|c|c|c|}
\hline & Group I ( $\mathrm{n}=21)$ & Group II (n = 19) & $\mathrm{p}$-value \\
\hline Age (years) & $52.76 \pm 10.5$ & $56.57 \pm 13.29$ & $0.588^{*}$ \\
\hline \multicolumn{4}{|l|}{ Gender } \\
\hline Female & $13(61.9)$ & 11 (57.9) & \multirow[t]{2}{*}{$0.796^{* *}$} \\
\hline Male & 8 (38.1) & $8(42.1)$ & \\
\hline BMI $(\mathrm{kg} / \mathrm{m} 2)$ & $27.8 \pm 4.17$ & $28.13 \pm 3.14$ & $0.774^{*}$ \\
\hline \multicolumn{4}{|l|}{ Level of Education } \\
\hline Illiterate & $3(14.3)$ & $4(21.1)$ & \multirow{5}{*}{$0.842^{* *}$} \\
\hline Primary & $10(47.6)$ & $8(42.1)$ & \\
\hline Secondary & $2(9.5)$ & $2(10.5)$ & \\
\hline High school & $3(14.3)$ & $4(21.1)$ & \\
\hline University & $3(14.3)$ & $1(5.3)$ & \\
\hline $\begin{array}{l}\text { Duration of disease } \\
\text { (months) }\end{array}$ & $55.6 \pm 44.4$ & $36.7 \pm 27.0$ & 0.101* \\
\hline \multicolumn{4}{|l|}{ Chronic disease } \\
\hline No & $7(33.3)$ & $8(42.1)$ & \multirow[t]{2}{*}{$0.567^{* *}$} \\
\hline Yes & 14 (66.7) & $11(57.9)$ & \\
\hline \multicolumn{4}{|l|}{ Orthosis use } \\
\hline No & $13(40.6)$ & $11(34.4)$ & \multirow[t]{2}{*}{$0.784^{* *}$} \\
\hline Yes & $19(59.4)$ & $21(65.6)$ & \\
\hline
\end{tabular}

*Mann-Whitney U test

**Chi-square test

Table 2 Intra- and intergroup comparisons of Barthel Index scores

\begin{tabular}{|l|l|l|l|}
\hline & Group I & Group II & p-value* \\
\cline { 2 - 4 } & $($ mean \pm SD $)$ & $($ mean \pm SD $)$ & \\
\hline Barthel Index & & & \\
\hline Pre-treatment & $63.33 \pm 24.8$ & $57.18 \pm 27.4$ & 0.434 \\
\hline Post-treatment & $65.19 \pm 21.7$ & $58.9 \pm 21.2$ & 0.293 \\
\hline p-value** & 0.064 & 0.345 & \\
\hline
\end{tabular}

SD: Standard deviation

*Mann-Whitney U test, **Wilcoxon signed-rank test

Table 3 Intra- and intergroup comparisons of Beck Hopelessness Scale scores

\begin{tabular}{|l|l|l|l|}
\hline & Group I & Group II & p-value* \\
\cline { 2 - 3 } & $($ mean \pm SD $)$ & $($ mean \pm SD $)$ & \\
\hline Beck Hopelessness Scale & & & \\
\hline Pre-treatment & $8.90 \pm 4.4$ & $10.31 \pm 3.6$ & 0.276 \\
\hline Post-treatment & $4.8 \pm 2.2$ & $7.94 \pm 4.1$ & 0.06 \\
\hline p-value** & 0.001 & 0.07 & \\
\hline
\end{tabular}

SD: Standard deviation

*Mann-Whitney U test, **Wilcoxon signed-rank test

Table 1 presents the distribution of some demographic and clinical features between the groups. No statistically significant difference was found between the two groups in terms of age, gender, level of education, BMI, disease duration, orthesis use, and the presence of chronic disease.

Table 2 shows the distribution of the Barthel Index scores, which were applied between the two groups and within each group. No statistically significant difference was found between or within the groups in terms of both pre- and post-treatment Barthel Index scores $(\mathrm{p}>0.05)$.

The average pre-treatment BHS score of all patients was $9.57 \pm 4.07$, while the average post-treatment score was $6.8 \pm$ 3.9. A significant difference was found in terms of the pre- and post-treatment BHS scores $(\mathrm{p}<0.05)$. Table 3 presents the intraand intergroup comparisons of the participants' BHS scores. A statistically significant difference was found between the preand post-treatment BHS scores of the patients included in the robotic rehabilitation programme $(\mathrm{p}<0.05)$, while no significant difference was found between the assessment results of the patients in the routine neurorehabilitation programme only $(\mathrm{p}$ $>0.05)$.

The average diagnosis period of the patients in the study was $46.7 \pm 37.2$ and it was found that $48 \%$ had not received any treatment previously. No association was found between the participants' pre- and post-treatment BHS scores and the diagnosis period of the disease $(p>0.05)$. A negative linear association was found between the BHS scores and the Barthel Index scores (pre-treatment $r=0.244$, post-treatment $r=0.311$ ).

\section{Discussion}

The effects of robot-assisted movement training on daily life activities and hopelessness levels in neurorehabilitation patients were investigated in this randomized controlled trial. A statistical difference was found between the pre- and posttreatment hopelessness levels of the patients included in the robotic rehabilitation programme $(\mathrm{p}<0.05)$, while no significant difference was found in the assessment results of the patients in the routine neurorehabilitation programme only.

When the pre-treatment scores of the assessed parameters were considered, it was found that the two groups were completely homogeneously distributed and that there were no statistical differences between the two groups. In terms of post-treatment, both groups were similar in the parameters other than hopelessness levels and there were no differences between the two groups.

In this study, the pre-treatment average BHS scores of all patients were $9.57 \pm 4.07$; their post-treatment average scores were $6.8 \pm 3.9$. This is a moderate level of hopelessness score. In a study that assessed the efficiency of clay therapy in neurology patients, the average BHS scores were $11.3 \pm 4.2$ and the post-treatment average scores were $7.24 \pm 2.97$. In another study that assessed the hopelessness levels of 320 hemodialysis patients, the average BHS scores were $9.63 \pm 5.56[16,17]$. Our results are in parallel with the literature. Hopelessness influences patients' compliance with the treatment, as well as their efforts and motivation. For this reason, we believe that in order to increase the success of rehabilitation in neurorehabilitation patients, strategies for coping with hopelessness should be an important aspect of rehabilitation programmes.

In this study, a statistical difference was found between the pre- and post-treatment BHS scores of the patients included in the robotic rehabilitation programme $(\mathrm{p}<0.05)$, while no significant difference was found in the assessment results of the patients in the routine neurorehabilitation programme only. There are a great number of studies in the literature examining the effects of gait training with a robotic device in neurorehabilitation patients. These studies have examined the effects of robotic rehabilitation on the locomotor system to a great extent $[18,19]$. However, only a limited number of studies have examined the neuropsychiatric effects of robotic rehabilitation. In these studies, it was found that robot-assisted movement training stimulated development in the patient's mood, cognitive state, and coping strategies [20]. This positive effect of robotic systems on mood and coping strategies may be partly related to computer-assisted visual feedback and task-oriented exercises [21]. In addition, in current study, a great number of the patients reported that they had been included in a neurorehabilitation programme previously (95.2\%). Robotic rehabilitation was considered as a new treatment method for these patients and this can explain the significant change in the hopelessness levels of the patients included in the robotic rehabilitation group.

No statistical difference was found within and between the 
groups in terms of both pre- and post-treatment Barthel Index scores. An increase was found in the Barthel Index scores when compared with pre-treatment, although the increase was not found to be significant. The Barthel Index measures physical and social functioning in daily life [22]. Neurorehabilitation practices are known to provide perceptive and cognitive development [8]. It is essential to provide perceptive and cognitive development in order to increase independence and functionality in DLAs. Mercier et al. reported that motor and perceptive disorders prevented functionality in DLAs [23]. In their randomized controlled study in which they compared the effects of rehabilitation and general care on the DLAs of stroke patients, Studenski et al. found that at the end of 6 months, the patients who were included in the rehabilitation programme had better quality of life levels when compared with the control group [24].

Robotic rehabilitation plays an active role in providing help to therapists, fulfilling motor learning principles, and conducting high intensity and long-term movements. Robotic systems also have a positive effect on patients' moods and coping strategies. Because of this, the interest in using robots in the treatment and follow-up of neurological patients has been gradually increasing. However, there are gaps about the possible side effects of these practices and other unknowns. Further studies are needed on the issue.

Disclosures: There is no conflict of interest for all authors.

\section{References}

1. Bishop DS, Pet LR. Physical medicine and rehabilitation: The American Psychiatric Press textbook of consultation-liaison psychiatry. Washington: American Psychiatric Press; 1996; 755-780.

2. Abramson I, Metalsky GL, Alloy L.B. Hopelessness depression: A theory-based subtype of depression. Psychological Review. 1989 ;96:358-372. https://doi.org/10.1037/0033-295X.96.2.358

3. Ercan F, Demir S. Hopelessness and quality of life levels in hemodialysis patients. GMJ. 2018; 29:169-174.

4. Suet-Ching WL. The quality of life for Hong Kong dialysis patients. J Adv Nurs. 2001; 35:218-27.https://doi.org/10.1046/j.13652648.2001.01839.x

5. Kınalı G. Differences in robotic rehabilitation according to clinic requirements. (2017). Available from: https://ieeexplore.ieee.org/ document/8238114/

6. Sheng Li. Spasticity, motor recovery, and neural plasticity after stroke. Front Neurol. 2017; 3(8):120. https://doi.org/10.3389/ fneur.2017.00120

7. Zhang X, Yue Z, Wang J. Robotics in lower-limb rehabilitation after stroke. Behav Neurol. 2017; 3731802. https://doi. org/10.1155/2017/3731802

8. Kayabınar E. The investigation of the effect of robotic and conventional gait training in addition to neurodevelopmental treatment on balance, mobility and health related quality of life in patients with stroke. (Basılmamış yüksek lisans tezi). Gazi Üniversitesi, Ankara, 2016.

9. Cao J, Xie SQ, Das R, Zhu GL. Control strategies for effective robot assisted gait rehabilitation: The state of art and future prospects. Med Eng Phys. 2014; 36:1555-66. https://doi.org/10.1016/j.medengphy.2014.08.005

10. Ozbudak SD. Robot-assisted gait training for patients with spinal cord injury. Turk J Phys Med Rehab. 2015; 61(1):37-44. https://doi. org/10.5152/tftrd.2015.59558

11. Mahoney FI, Barthel DW. Functional evaluation: The Barthel Index. Maryland State Med J. 1965; 14:61-5.

12. Kucukdeveci AA, Yavuzer G, Tennant A, Süldür N, Sonel B, Arasil T. Adaptation of the modified Barthel Index for use in physical medicine and rehabilitation in Turkey. Scand J Rehabil Med. 2000; 32(2):87-92. https://doi.org/10.1080/003655000750045604

13. Beck AT, Wiessman A, Lester D, Trexler L. The measurement of pessimism: The hopelessness scale. J Consult Clin Psychol. 1974; 42:861-5. https://doi.org/10.1037/h0037562

14. Seber G, Dilbaz N, Kaptanoglu C, Tekin D. Hopelessness Scale: Validity and reliability. Journal of Crisis. 1993; 1(3):139-142.

15. Durak A, Palabıyıkoğlu R. The validation study of the Beck's hopelessness scale. Journal of Crisis. 1994; 2:311-69.

16. Akhan LU, Kurtuncu M, Celik S. The effect of art therapy with clay on hopelessness levels among neurology patients. Rehabilitation Nursing. 2017; 42(1):39-45. https://doi.org/10.1002/rnj.215

17. Ercan F, Demir S. Hopelessness and quality of life levels in hemodialysis patients. GMJ. 2018; 29:169-174.

18. Wallard L, Dietrich G, Kerlirzin Y, Bredin, J. Effects of robotic gait rehabilitation on biomechanical parameters in the chronic hemiplegic patients. Clinical Neurophysiology. 2015; 45:215-219. https://doi.org/10.1016/j.neucli.2015.03.002

19. Krishnan C, Kotsapouikis D, Dhaher YY, Rymer WZ. Reducing robotic guidance during robot-assisted gait training improves gait function: A case report on a stroke survivor. Archives of Physical Medicine and Rehabilitation. 2013; 94:1202-1206. https:/doi. org/10.1016/j.apmr.2012.11.016

20. Calabro RS, Reitano S, Leo A, De Luca R, Melegari C, Bramanti P. Can robot-assisted movement training (Lokomat) improve functional recovery and psychological well-being in chronic stroke? Functional Neurology. 2014; 29(2):139-141. http://dx.doi.org/10.11138/ FNeur/2014.29.2.139

21. Banz R, Bolliger M, Colombo G, et al. Computerized visual feedback: An adjunct to robotic-assisted gait training. Phys Ther. 2008; 88:1135-1145. https://doi.org/10.2522/ptj.20070203

22. Murcia J, Llorens P, Sánchez-Payá J, Reus S, Boix V, Merino E, Laghzaoui F, Portilla J. Functional status determined by Barthel Index predicts community acquired pneumonia mortality in general population. $J$ Infect. 2010; 61(6):458-64. https://doi.org/10.1016/j. jinf.2010.08.006

23. Mercier L, Audet T, Hebert R, Rochette A, Dubois MF. Impact of motor, cognitive, and perceptual disorders on ability to perform activities of daily living after stroke. Stroke. 2001; 32:2602-2608. https://doi.org/10.1161/hs1101.098154

24. Studenski S, Duncan PW, Perera S, Reker D, Lai SM, Richards, L. Daily functioning and quality of life in a randomized controlled trial of therapeutic exercise for subacute stroke survivors. Stroke. 2005; 36:1764-1770. https://doi.org/10.1161/01.STR.0000174192.87887.70

How to cite this article: Filiz Ozdemir, Fatma Oksuz, Tuba Tulay Koca. The effects of robot-assisted movement training on daily life activities and hopelessness levels in neurorehabilitation patients. J Clin Med Kaz. 2019; 1(51):56-60 